\title{
Antibacterial Activities of Crude Leaf and Bark Extracts of "Icheku" Dialium guineense on Bacterial Isolates from Bronchitis Patients
}

\author{
${ }^{1}$ Orji, J.O., ${ }^{2}$ Alo, M.N., ${ }^{1}$ Anyim, C.* and ${ }^{1}$ Okonkwo, E.C. \\ ${ }^{1}$ Department of Applied Microbiology, Ebonyi State University, Abakaliki, Nigeria. \\ ${ }^{2}$ Department of Medical Laboratory Science, Ebonyi State University, Abakaliki, Nigeria.
}

\begin{abstract}
The antibacterial activities of aqueous and ethanolic leaf and bark extracts of Dialium guineense were evaluated against clinical isolates of Klebsiella pneumoniae and Staphylococcus aureus using agar well diffusion technique. The photochemical analysis of Dialium guineense extracts were also carried out. The results showed that the extracts at varying concentrations, exerted antibacterial activities on the test organisms. The highest inhibition diameter $(18 \mathrm{~mm})$ at $0.8 \mathrm{~g} / \mathrm{ml}$ was recorded for cold water leaf extracts against Staphylococcus aureus and ethanol extracts inhibited the growth of the bacterial isolates in concentration dependent manner with minimum inhibitory concentration dependent manner with minimum inhibitory concentration (MIC) at $0.2 \mathrm{~g} / \mathrm{ml}$. The result of the physicochemical analysis showed the presence of flavonoids, alkaloids, tannin and saponin. These results suggest further exploitation of this material to possibly unveil its potential use for the treatment of diseases caused by the test organisms.
\end{abstract}

Keywords: Dialium guineense, Antibacterial, phytochemical, bronchitis patients

\section{INTRODUCTION}

Dialium guineense is a tree of an average height of $30 \mathrm{~m}$ with densely leafy crown, smooth greyish bark. Leaves are hairy and the flowers are usually whitish while the fruits are less circular and flattened. The pulp of the fruit is edible and sweet, fairly low levels of ascorbic acid and tannin are present. It is a fairly good source of protein and minerals [1]. Dialium guineense can also be found in West African countries such as Ghana where it is known as Yoyi, Sierra Leone, Senegal, and Nigeria where it is known as Awin in Yoruba, Icheku in Igbo and Tsamiyar kurm in Hausa [2] and [3].

The bark and leaves of $\mathrm{D}$. guineense have medicinal properties and are used against several diseases. The fruits of the plant are chewed among some women in southeast Nigeria to improve lactation and check genital infection [2]. D. guineense is used as chewing stick (indigenous tooth brush) among Nigerian populace [3]. Okwu and Ekeke [4] reported in their studies that the plant contains saponin which is presumed to add to the cleaning effect of teeth and at the same time prevent caries and plaques on the teeth of the users. Dialium guineense leaves and stem bark are used as folklore remedies for the treatment of infections such as diarrhoea, severe cough, bronchitis, wound, stomachaches, malaria fever, jaundice, antiulcer and haemorrhoids [5].

The work was aimed at ascertaining the antibacterial potentials and phytochemicals of Dialium guineense extracts on Staphylococcus aureus and Klebsiella pneumoniae isolated from sputum of bronchitis patients in Abakaliki, South-Eastern Nigeria.

\section{Collection of plant material}

\section{MATERIALS AND METHODS}

Fresh leaves of Dialium guineense were collected from Mgbabor-Achara in Ezza South Local Government Area of Ebonyi State, Nigeria. The plants were identified and authenticated by Prof. S.C.C. Onyekwelu (taxonomist) at the Department of Applied Biology, Ebonyi State University, Abakaliki, Ebonyi State. The plant leaves and barks were rinsed in sterile distilled water and later dried in the hot-air oven at $60^{\circ} \mathrm{C}$ for 12 hours. These were stored in airtight glass containers protected from sunlight until required for analysis.

\section{Extract Preparation}

Exactly $20 \mathrm{~g}$ of pulverized bark each was respectively dissolved in $100 \mathrm{ml}$ of ethanol, cold water and hot water (boiled for 20 minutes). They were allowed to stand for 24 hours, with intermittent agitation for 6 hours. The same quantity of the grounded leaves were similarly dissolved in ethanol, cold and hot water. They were also 
intermittently agitated for 6 hours. subsequently, they were respectively sieved into different sterile containers using Whatman No. 1 filter paper. The filtrates were concentrated and dried using water bath at $40^{\circ} \mathrm{C}[6]$.

Different concentrations of the extracts were made in sterile distilled water. This was done by dissolving $0.1 \mathrm{~g} / \mathrm{ml}, 0.2 \mathrm{~g} / \mathrm{ml}, 0.4 \mathrm{~g} / \mathrm{ml}, 0.6 \mathrm{~g} / \mathrm{ml}$ and $0.8 \mathrm{~g} / \mathrm{ml}$ of each extract into corresponding volumes of distilled water.

\section{Determination of microbial activity of the extracts}

Agar well diffusion technique as described by Cheesbrough [7] was used to determine the antibacterial activity of the extracts. The test organisms were respectively diluted to $0.5 \%$ McFarland equivalent standard [7]. An $18 \mathrm{ml}$ of Nutrient agar plates that has been checked for sterility were seeded with $2 \mathrm{ml}$ of an overnight broth culture of each bacterial isolate in sterile Petri-dish. The seeded plates were allowed to set after a uniform distribution of the bacterial isolate following slow rotation of the Petri dish. A standard sterile cork borer of $8 \mathrm{~mm}$ diameter was used to cut uniform wells on the surface of the agar. The wells filled with $2 \mathrm{ml}$ of each extracts were with the aid of a sterile syringe. One of the well in each Nutrient agar plate was filled with $250 \mathrm{mg}$ of Augmentine served as a control. The plates were then allowed to stand for 1 hour at room temperature to allow proper diffusion of the extract to occur. All the plates were incubated at $37{ }^{\circ} \mathrm{C}$ for 24 hours and observed for zones of inhibition. A zone of clearance round each well signifies inhibition and the diameter of such zones were measured in millimeter (mm). The minimum inhibitory concentration (MIC) in $\mathrm{mg} / \mathrm{ml}$ was determined by comparing the different concentration of the extracts that have different zones of inhibition and then selecting the lowest concentration of each extract [8].

\section{Preliminary phytochemical screening test for the extract}

A small portion of the dry extract was subjected to the phytochemical test using Harborne [9] methods to identify the active constituents (alkaloids, flavonoids and tannins).

\section{RESULTS}

The result of the research indicated that two (2) bacterial isolates are implicated in this study. They encompasses Staphylococcus aureus - are Gram positive, catalase positive, indole negative' coagulase positive and Dnase positive while Klebsiella pneumonia are Gram negative, oxidase negative, urease positive, citrate positive and Voges proskeur positive. Both organisms show negative reaction to motility test. Staphylococcus aureus show white creamy in colour and mucoid slightly raised surface in consistency while Klebsiella pneumoniae shows milky white in colour, mucoid with raised surface in consistency.

Table 1: Characteristic properties of bacterial isolates

\begin{tabular}{|c|c|c|c|c|c|c|c|c|c|c|c|c|c|c|}
\hline $\mathbf{S} / \mathbf{N}$ & Colour & $\begin{array}{l}\text { Consistency } \\
\text { texture }\end{array}$ & $\begin{array}{l}\text { Microscopical } \\
\text { Staining }\end{array}$ & $\begin{array}{l}\text { Gram } \\
\text { Features }\end{array}$ & 离 & 若 & $\frac{\stackrel{0}{0}}{g}$ & 产 & 苟 & 莡 & : & $\begin{array}{l}\tilde{\Xi} \\
\stackrel{\tilde{a}}{a}\end{array}$ & 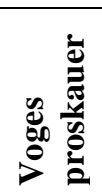 & $\begin{array}{l}\text { Suspected } \\
\text { Isolates }\end{array}$ \\
\hline 1 & White & Creamy & $\begin{array}{l}\text { Spherical in } \\
\text { clustered form }\end{array}$ & $\begin{array}{l}\text { Gram } \\
\text { positive(+) }\end{array}$ & + & - & - & - & + & - & - & + & - & S. aureus \\
\hline 2 & $\begin{array}{l}\text { Milky } \\
\text { white }\end{array}$ & $\begin{array}{l}\text { Mucoid, } \\
\text { slightly raise } \\
\text { surface }\end{array}$ & $\begin{array}{l}\text { Bacilli rods } \\
\text { form }\end{array}$ & $\begin{array}{l}\text { Gram } \\
\text { negative } \\
(-) \text { rods }\end{array}$ & - & - & - & - & - & + & + & - & + & K. pneumoniae \\
\hline
\end{tabular}

Key: $+=$ positive reaction, $-=$ Negative reaction 
Table 2: Inhibitory zone diameter of aqueous cold water leaf and bark extracts of Dialium guineense on Klebsiella pneumoniae.

\begin{tabular}{lll}
\hline Extract Concentration $(\mathbf{g} / \mathbf{m l})$ & \multicolumn{2}{l}{ Inhibition Zone diameter } \\
\cline { 2 - 3 } & Leaf & Bark \\
\hline 0.1 & $\mathrm{NI}$ & $\mathrm{NI}$ \\
0.2 & 8 & 4 \\
0.4 & 10 & 6 \\
0.6 & 12 & 8 \\
0.8 & 14 & 10 \\
Control (Augmentine) & 20 & 15 \\
\hline
\end{tabular}

Key: NI = No inhibition

The result on inhibitory zone diameter of aqueous cold water leaf and bark extracts of Dialium guineense on Staphylococcus aureus in shown in table 3. It revealed that both cold water leaf and bark extracts had activities on Staphylococcus aureus varying concentrations. The cold water leaf extracts had highest inhibition zone diameter of $18 \mathrm{~mm}$ at $0.8 \mathrm{~g} / \mathrm{ml}$ and lowest inhibitory zone diameter of $12 \mathrm{~mm}$ at $0.4 \mathrm{~g} / \mathrm{ml}$.

Meanwhile, the cold water bark extract also had highest inhibitory zone diameter of $12 \mathrm{~mm}$ at $0.8 \mathrm{~g} / \mathrm{ml}$ and lowest inhibition zone diameter of $10 \mathrm{~mm}$ at $0.4 \mathrm{~g} / \mathrm{ml}$.

The minimum inhibitory concentration (MIC) was $0.4 \mathrm{~g} / \mathrm{ml}$.

Table 3: Inhibitory zone diameter of aqueous cold water leaf and bark extracts of Dialium guineense on Staphylococcus aureus.

\begin{tabular}{lll}
\hline Extract Concentration $(\mathbf{g} / \mathbf{m l})$ & \multicolumn{2}{l}{ Inhibition Zone diameter } \\
\cline { 2 - 3 } & Leaf & Bark \\
\hline 0.1 & NI & NI \\
0.2 & NI & NI \\
0.4 & 12 & 10 \\
0.6 & 14 & 10 \\
0.8 & 18 & 12 \\
Control (Augmentin) & 20 & 15 \\
\hline
\end{tabular}

Key: NI $=$ No inhibition

Table 4: Inhibitory zone diameter of ethaonolic leaf and bark extracts of Dialium guineense on Klebsiella pneumoniae.

\begin{tabular}{lll}
\hline Extract Concentration $(\mathbf{g} / \mathbf{m l})$ & \multicolumn{2}{l}{ Inhibition Zone diameter } \\
\cline { 2 - 3 } & Leaf & Bark \\
\hline 0.1 & NI & NI \\
0.2 & 16 & 14 \\
0.4 & 17 & 15 \\
0.6 & 18 & 15 \\
0.8 & 18 & 16 \\
Control (Augmentin) & 20 & 15 \\
\hline
\end{tabular}

Key: NI = No inhibition

The result of inhibitory zone diameter of ethanolic leaf and bark extracts of Dialium guineense on Staphylococcus aureus is shown on table 5. It revealed that both ethanolic leaf and bark extracts had activities on Staphylococcus aureus at varying concentrations. The ethanolic leaf extracts had highest inhibitory zone diameter of $18 \mathrm{~mm}$ at $0.8 \mathrm{~g} / \mathrm{ml}$ and lowest inhibitory zone diameter of $14 \mathrm{~mm}$ at $0.2 \mathrm{~g} / \mathrm{ml}$.

Meanwhile, the ethanolic bark extract also had highest inhibitory zone diameter of $16 \mathrm{~mm}$ at $0.8 \mathrm{~g} / \mathrm{ml}$ and lowest inhibitory zone diameter of $12 \mathrm{~mm}$ at $0.2 \mathrm{~g} / \mathrm{ml}$. 
The minimum inhibitory concentration (MIC) was $0.2 \mathrm{~g} / \mathrm{ml}$.

Table 5: Inhibitory zone diameter of ethaonolic leaf and bark extracts of Dialium guineense on Staphylococcus aureus.

\begin{tabular}{lll}
\hline Extract Concentration $(\mathbf{g} / \mathbf{m l})$ & \multicolumn{2}{l}{ Inhibition Zone diameter } \\
\cline { 2 - 3 } & Leaf & Bark \\
\hline 0.1 & NI & NI \\
0.2 & 14 & 12 \\
0.4 & 16 & 14 \\
0.6 & 17 & 14 \\
0.8 & 18 & 16 \\
Control (Augmentin) & 20 & 15 \\
\hline
\end{tabular}

Key: NI = No inhibition

The result on inhibitory zone diameter of hot water leaf and bark extracts of Dialium guineense on Staphylococcus aureus is shown on table 6. It reveals that both hot water leaf and bark extracts had no inhibitory activity on Staphylococcus aureus at varying concentrations.

Table 6: Inhibitory zone diameter of hot leaf and bark extracts of Dialium guineense on Staphylococcus aureus.

\begin{tabular}{lll}
\hline Extract Concentration $(\mathbf{g} / \mathbf{m l})$ & \multicolumn{2}{l}{ Inhibition Zone diameter } \\
\cline { 2 - 3 } & Leaf & Bark \\
\hline 0.1 & NI & NI \\
0.2 & NI & NI \\
0.4 & NI & NI \\
0.6 & NI & NI \\
0.8 & NI & NI \\
Control (Augmentin) & 20 & 15 \\
\hline
\end{tabular}

Key: NI = No inhibition

The result on inhibitory zone diameter of hot water leaf and bark extracts of Dialium guineense on Klebsiella pneumoniae is shown on table 7. It reveals that both hot water leaf and bark extracts had no inhibitory activity on Klebsiella pneumoniae at varying concentrations.

Table 7: Inhibitory zone diameter of hot leaf and bark extracts of Dialium guineense on Klebsiella pneumoniae.

\begin{tabular}{lll}
\hline Extract Concentration $(\mathbf{g} / \mathbf{m l})$ & \multicolumn{2}{l}{ Inhibition Zone diameter } \\
\cline { 2 - 3 } & Leaf & Bark \\
\hline 0.1 & NI & NI \\
0.2 & NI & NI \\
0.4 & NI & NI \\
0.6 & NI & NI \\
0.8 & NI & NI \\
Control (Augmentin) & 20 & 15 \\
\hline
\end{tabular}

Key: NI $=$ No inhibition

\section{DISCUSSION}

In addition to the usefulness of Dialium guineense as a good sources of food to man [10], the result of this study revealed that it also has antimicrobial properties against Staphylococcus aureus and Klebsiella pneumoniae at varying degrees. This finding is interesting essentially at the present time where the problems of emerging and reemerging resistant strains of microorganism are becoming the order of the day. Some researchers have reported that microorganism do not easily develop resistance against natural products [11]. Another point which underscores the relevance of this finding is that medicinal plants are said to promote homeostatic balance in patients and are relatively less toxic than synthetic drugs [10]. Remarkably, Dialium guineense plant is readily available in Nigeria. 
It is further observed that the ethanolic extracts of the planet materials was the most effective against the test organisms. This could be an indication that the active ingredients in the plant bark and leaf are more soluble in ethanol than water. Previous study has emphasized that antimicrobial property of plants extracts varies with different solvents used in extraction [11]. The hot water extract did not inhibit the growth of any of the test organism, this according to Chen et al. [12] may be explained by the facts that the extract which are mainly organic compounds are destroyed by heat from the hot water which might have raised the temperature of the extract thereby inactivating them.

It is worthy of noted that antimicrobial activities of the plant extract was dependent on the concentration of the extract and the molecular weight of the extract, this in accordance with previous report by Ekwenye and Elegalam [13] that if the extract has high molecular weight, the rate of diffusion is always slow, reduced and also takes longer time, whereas an extract of low molecular weight diffuses faster and at a quicker time.

The physiochemical analyses of Dialium guineense bark and leaf extract revealed the presence of flavonoids, alkaloids, tannin and saponin.

The medicinal values of these constituents have long been highlighted [14].

\section{CONCLUSION}

The observed antimicrobial effects of Dialium guineense leaf and bark extracts on the test organism used, though in vitro appear interesting and promising. This implies that the plant extracts may be indeed effective in management of bronchitis, supporting its ethno-medicinal use; thus the plant presented as potential source of novel antimicrobial drugs.

Consequently, further exploitation of this plant product, for probable preparation of cheap and efficacious antibacterial therapy is hereby recommended.

\section{REFERENCES}

[1] S.S. Arogba, A.A. Ajiboro and I.J. Odukwe, A physico-chemical study of Nigerian velvet tamarind Dialium guineense L.) fruit. $J$ Sc Food Agric, 66: 533-534 (2006).

[2] M.O. Nwosu, Plant resources used by traditional women as herbal medicine and cosmetics in Southwest Nigeria. Arzte fur Natur Fahr, 41:11 (2000).

[3] A.D. Akinpelu, T.O. Awotorebo, O.M. Agunbiade, A.O. Aiyegoro and I.A. Okoh, Anti-Vibrio and preliminary phytochemical characteristics of crude methanolic extracts of the leaves of Dialium guineense (Wild). Journal of Medicinal Plants Research, 5(11): 2398-2404 (2011).

[4] D.E. Okwu and O. Okeke, Phytochemical screening and mineral composition of chewing sticks in South Eastern Nigeria. Glo J Pur Appl Sci, 9(2): 235-238 (2003).

[5] J. Bero, H. Ganfon, M.C. Jonville, M. Frederich, F. Gbaguidi, M.P. De, M. Moudachirou and L.J. Quetin, In vitro antiplasmodial activity of plants used in Benin in traditional medicine to treat malaria. J Ethnopharmacol, 122(3): 439-444 (2009).

[6] M.B. Ibrahim, M.O. Owonubi and J.A. Onulapo, Antibacterial effects of leaf, stem, and root bark of Angiesues leicarpus on Staphylococcus aureus_NLTc6571, Streptococcus pyogenes NCTC 8198, Escherichia coli NCTC 10458 and Proteus vulgaris NCTC 4636. J of Pharmcdent Res Dev 2: 20-26 (2002).

[7] M. Cheesbrough, District laboratory practice in tropical countries, Part 2. Cambridge University Press, Cambridge, UK. PP. 137150 (2006).

[8] C. Agatemor, Antimicrobial activity of aqueous and ethanol extracts of nine Nigerian spices against four food borne bacteria. Elec $J$ Environ Agric Food Chem, 8(3): 195-200 (2009).

[9] J.B. Harborne, Textbook of phtochemical method: Aguide to modern technique of plant analysis. 2nd edition, Champenan and Hall Limited. PP. 99-103. (1974).

[10] B.O. Obadori and P.O. Ochuko, Phytochemical studies and comparative efficacy of the guide extracts of some home state plants in Edo and Delta State of Nigeria. Global Journal of Pure and Applied Sciences, 81: 203-208 (2001).

[11] H.O., Edeoga, D.E. Okwu, and B.O. Mbaebie, Phytochemical constituents of some Nigerian medicinal plants. African Journal of Biotechnology, 4(7): 685-688 (2005).

[12] Q.Y. Chen, H. Shi and C.T. Ho, Effects of Rosemary Extracts and Major Constituents on Lipid Oxidation and Soybean Lipoxygenase Activity. Journal of the American Oil Chemists Society, 69(10): 999-1002 (1992).

[13] V.N. Ekwenye and N.N. Elegalon, Antibacterial activity of ginger (Zingiber offinale Roseoe) and garlic (Alilium salivium) extracts on Escherichia coli and Klebsiella pneumoniae. Journal of Molecular Medicine and Advanced Science, 1(4): 411-416 (2005).

[14] M. Lever, D.A. Vandon-berghe, F. Mertend, A. Vlictinck and E. Lammens. Screening of higher plants for biological activities/antimicrobial activity. Plants Medica, 36: 311-321 (2000) 